\title{
Evaluation Program of Student League Competition U-12 Menpora Cup 2017
}

\author{
Budi Ariyanto Muslim \\ Department of Sport Education \\ State University of Jakarta \\ Jakarta, Indonesia \\ budiariyantomuslim@gmail.com
}

\author{
Taufik Hidayat Suharto \\ Department of Sport Education \\ State University of Jakarta \\ Jakarta, Indonesia \\ taufik.hidayat.suharto.ths@ gmail.com
}

\author{
Tommy Rizki Prasetyo \\ Department of Sport Education \\ State University of Jakarta \\ Jakarta, Indonesia \\ qyqytomy@gmail.com
}

\begin{abstract}
The purpose of this study is to evaluate the Program of Student League Competition U-12 Menpora Cup 2017. This research uses qualitative techniques with an evaluation approach using the Context model, Input, Process, and Product (CIPP). Methods of data collection in triangulation using questionnaires, interviews, document studies and observation. The results show that in: (1) Context Evaluation: has a very strong legal basic and government policies, intentions and objectives well, but not yet targeted. (2) Input Evaluation: participants, organizing, financing and committees have not been implemented properly, and need to be improved in accordance with the development of the Student League Competition U-12 Menpora Cup every year. (3) Process Evaluation: sports competition rules that must always be updated in accordance with the development of football, the implementation of the competition still needs to be maximized well. (4) Product Evaluation: increased participation and public interest in organizing the Student League Competition U-12 Menpora Cup every year, the role of media in the publication and promotion of sports to the community is increasingly expanded, and the search for seeds of potential sportsmen from the community that needs to be optimized. However, athlete achievement has not contributed much to the achievement of the world level.
\end{abstract}

Keywords: program evaluation, Student League Competition U-12 Menpora Cup

\section{INTRODUCTION}

Sports education is part of the coaching mandated in Law number 3 of 2005 concerning the National Sports System. The government as the highest institution that regulates the prosperity of the Indonesian people has a very important role in shaping the nation's character through sports. Kemenpora as part of the Indonesian government which deals with youth and sports.

The Ministry of Youth and Sports as the representative of the Government seeks to foster and improve overall sports achievements in accordance with the Government program that will be proclaimed, be it sports education, recreational sports or performance sports.

One of the great homework for the government to this day is found in soccer. Indonesian football, which is currently of poor concern. The condition of Indonesian football is currently far behind compared to a number of other Asian countries. At the level of Southeast Asia alone, in the last 10 years, our achievement was only one champion in the AFF U19 Cup event in 2013. This could occur due to several factors that affect one of them, namely the problem of coaching and improving sports. The underdevelopment of Indonesia's soccer achievements requires a fundamental improvement. It is starting with the focus on fixing the development of a young age as its foundation. In order for youth development to work well, the Government needs to facilitate various competitions in the U-12 to U-16 groups.

The U-12 Student League Menpora Cup 2017 is one of the leading annual programs in the work program of the Minister of Youth and Sports in the context of fostering and enhancing the achievements of soccer in Indonesia. The main objective is to recruit talented soccer athletes in all regions of Indonesia, starting from the basic level to the professional level for long-term and sustainable development.

The U-12 Student League Menpora Cup 2017 is a place for U-12 group competition that aims to attract the best young footballers to strengthen the national team in the International level according to their age level and become part of the ladder of youth development in stages and provide a place for activities that are positive among students to prevent the dangers of drug use and other negative behaviors.

The U-12 Student League (LPU-12) Menpora Cup 2017 is held in stages from the Region Series, Provincial Series, until it reaches the top of the National Series which is joined by 34 Provincial Series championship teams. Thus, the LPU-12 2017 Menpora Cup involves around 72 thousand young players. In principle, each Province is divided into 6 (six) regions by considering the principle of representation and geographical closeness so that LPU-12 is joined by more student soccer teams in the country. Each region is joined by 12-16 participating clubs. Thus, the number of participating clubs participating in the U-12 Student League for the 2017 Menpora Cup reached more than 3 thousand clubs.

The implementation of the 2017 U-12 Menpora Cup Student League must certainly be evaluated considering that this activity is spread throughout the districts and cities in Indonesia. This is done to see the extent of the implementation of the U-12 Student League Menpora Cup in 2017 whether it is in accordance with the objectives to be 
achieved, in accordance with the program being run or in accordance with the desires expected. This effort was made to realize the holding of the 2017 Menpora Cup U-12 Student League in accordance with the desired expectations. Both in terms of preparation, outreach and registration, regional and national series to the results achieved. Based on this the researcher would like to evaluate more deeply about the 2017 Menpora Cup U-12 Student League Program.

\section{Methodology}

The research was carried out through a program evaluation approach with a descriptive method. The descriptive method is a method that is done by describing the findings made through problem-solving procedures, investigated by describing or describing the state of the subject/object of research (a person, institution, community, etc.) (Paranoan \& Nur, 2019). For this reason, this method was formed in order to be able to provide findings on the evaluation of the 2017 U-12 Cup of the Menpora Cup and describe them in detail.

To find out more in-depth information about the U-12 Student League Cup Menpora 2017 program researchers used design as a concept in starting the evaluation of the U12 Student League Cup Menpora 2017. The use of the design in this study using the CIPP research design can provide an overview of the influence and system improvement provided by the design, for that design description can be seen in the image below:

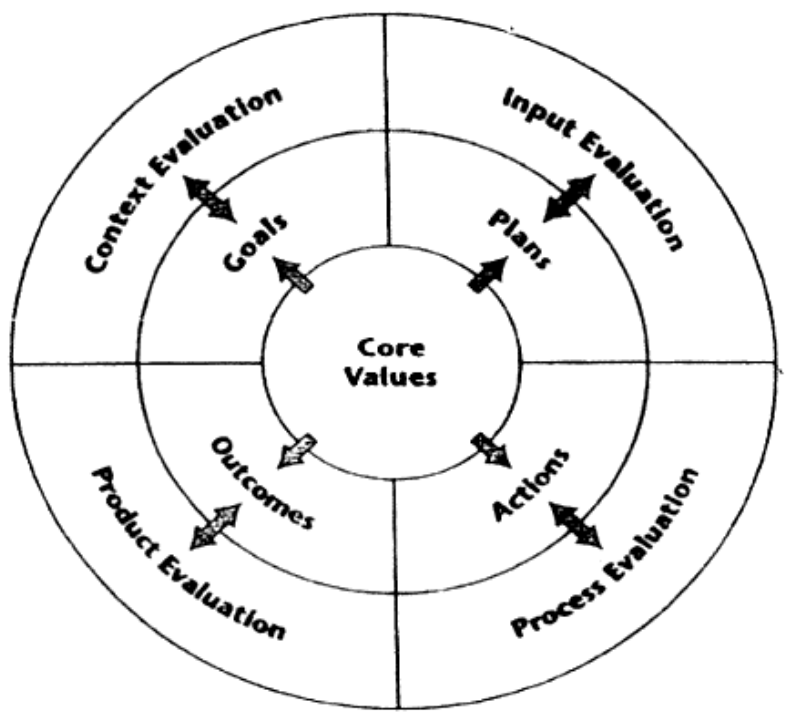

Fig. 1. Stages and Processes of the CIPP Model Evaluation Model and Their Effects on System Improvement.

Source: James Tangkudung., Macam-Macam Metodologi Penelitian (Uraian dan Contohnya), (Jakarta: Penerbit Lensa Media Pustaka Indonesia, 2016), h. 90

For further elaboration on the design to be carried out as well as the groupings that will be carried out later will be discussed in detail in the image at Figure 2.

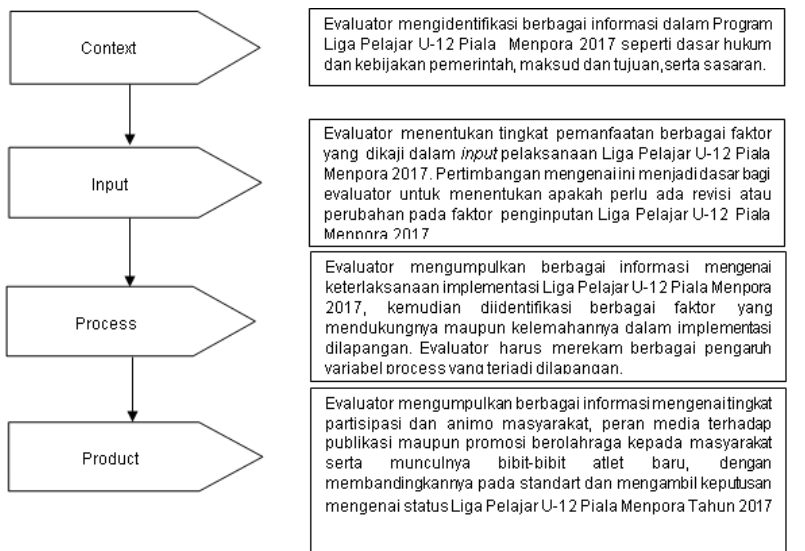

Fig. 2. Research Flow Evaluation of 2017 Menpora Cup U-12 Student League Program.

Source: James Tangkudung., Macam-Macam Metodologi Penelitian (Urainan dan Contohnya), (Jakarta: Pnerbit Lensa Media Pustaka Indonesia, 2016), h. 100

The research design of the 2017 Menpora Cup U12 Student League Evaluation Program can be seen below:

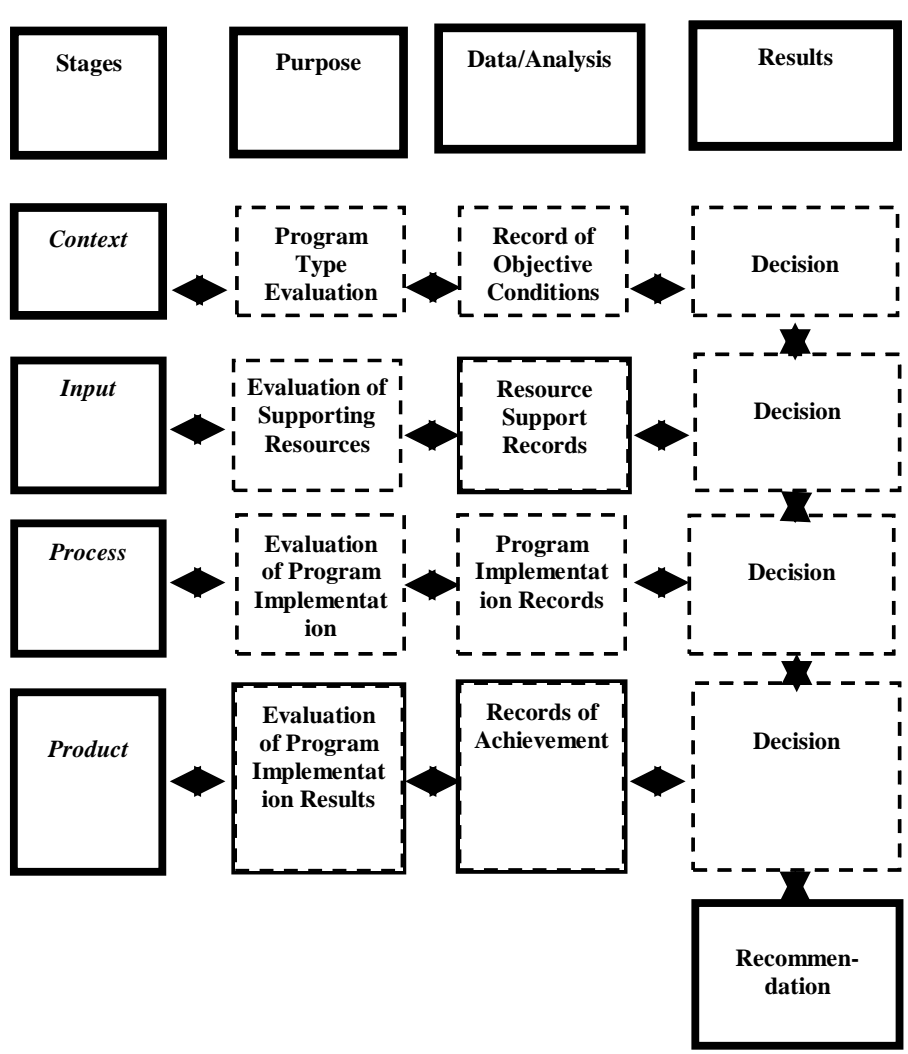

Fig. 3. Design Evaluation of the CIPP Model

Source: Daniel L. Stufflebeam \& Anthony J. Shinkfield, Evaluation Theory, Models, \& Applications, (United States of America: Jossey-Bass, A Wiley Brand, 2007), h.326.

Retrieval of data was carried out to find out the results of the 2017 Menpora Cup U-12 Student League Program 
basis and government policy, 2) goals and objectives, 3) objectives, it appears that of the 300 respondents turned out 166 respondents $(53.63 \%)$ stated very good, 82 respondents $(27.49 \%)$ stated good, 47 respondents $(15.76 \%)$ stated that it was quite good, 9 respondents $(3.12 \%)$ stated that it was not good, and almost none respondents who stated that they were not good. It can be concluded that overall for the evaluation of sub-context programs which include three things, namely: 1) legal basis and government policy, 2) purpose and objectives, 3) objectives are categorized very well.

After knowing the results of data calculated using a quantitative approach the next step is to check the data based on the results of the study of documents and the results of interviews. The results of quantitative calculations will check the validity of the data whether it is in accordance with the results of the study documents and the results of the interview. The results of the study documents and the results of the interview will describe in detail according to the indicators to obtain correct data.

\section{B. Input Evaluation}

Evaluation of the implementation of the 2017 Menpora Cup U-12 Student League program next is input evaluation. Input evaluation is intended to identify the objective conditions of resource support that support the implementation of the U-12 Student League Cup Menpora in 2017 (Galvin, 1992). Based on this, the sub-focus of input evaluation includes four things, namely: 1) participants, 2) implementation, 3) financing, 4) committee. The results are presented in the table as follows:

TABLE II. EVALUATION RESUlts OF SUb INPUT PROGRAMS

\begin{tabular}{|c|c|c|c|}
\hline Score & Frequency & Percent & Category \\
\hline 5 & 127 & $42,39 \%$ & Very good \\
\hline 4 & 45 & $15,06 \%$ & Well \\
\hline 3 & 41 & $13,74 \%$ & Pretty good \\
\hline 2 & 69 & $22,98 \%$ & Not good \\
\hline 1 & 17 & $5,83 \%$ & Poor \\
\hline Amount & 300 & $100 \%$ & - \\
\hline
\end{tabular}

While in the form of bar charts can be seen in Figure 5 below:

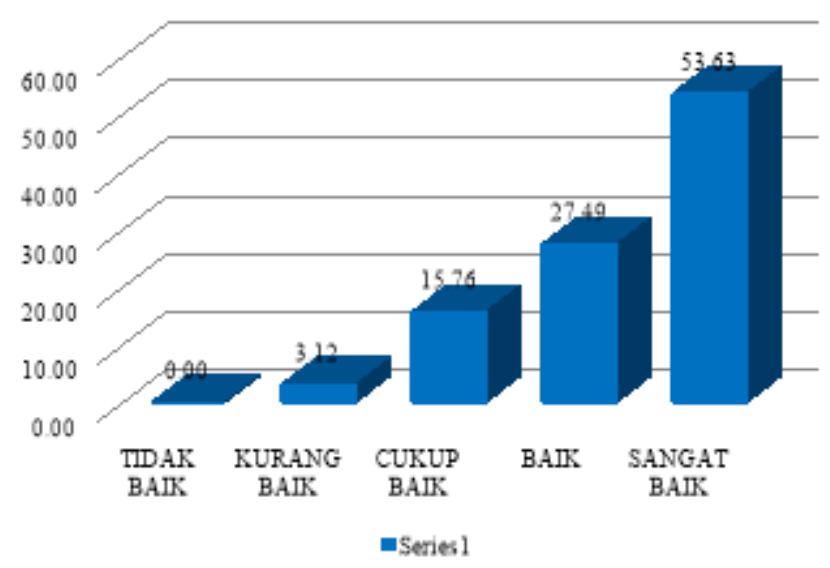

Fig. 4. Bar Diagram of Sub Context Program Evaluation Results

Based on Table 1 and Figure 4 bar diagram above about the results of research sub-focus data from the context evaluation which includes three things, namely: 1) legal

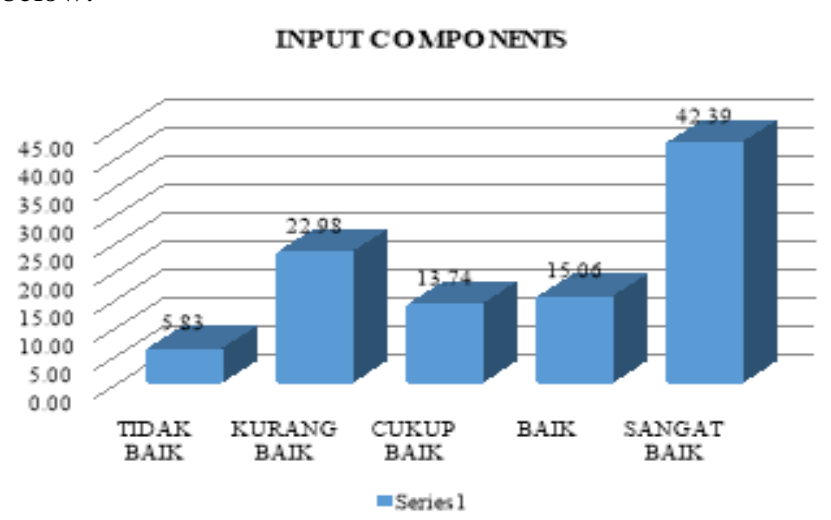

Fig. 5. Bar Diagram of Sub Input Program Evaluation Results

Based on Table 2 and Figure 6 bar diagram above about the results of research sub-focus data from the evaluation of inputs include four things, namely: 1) participants, 2) implementation, 3) financing 4) committee, it appears that 
interest 4) the emergence of potential sportsman seeds from the community. The results of the input evaluation of 300 respondents stated 88 respondents $(29.25 \%)$ stated very good, 66 respondents $(21.93 \%)$ said good, 92 respondents $(30.77 \%)$ stated quite well, 46 respondents $(15.33 \%)$ stated that it was not good, and 8 respondents $(2.71 \%)$ said it was not good. Thus it can be concluded that the results of the evaluation process of the sub-process include five things, namely: 1) competition rules, 2) implementation, 3) the level of community participation and interest 4) the emergence of potential sportsmen seeds from the community are categorized as good.

The results of the study documents and the results of the interview will describe in detail according to the indicators to obtain correct data. Sub indicators in the evaluation process include: 1) competition rules, 2) implementation is categorized well in the U-12 Student League Menpora Cup 2017.

\section{Product Evaluation}

Product evaluations describe and detail the environmental needs, namely clarity about the level of participation and public interest, the role of the media in publications and promotion of sports to the community, and the emergence of potential sportsmen seeds from the community (Palmizal, 2017). The results are presented in Table 4 as follows:

TABLE IV. Sub Product EVALUATION RESUlts

\begin{tabular}{|l|l|l|l|}
\hline Score & Frequency & Percent & Category \\
\hline 5 & 59 & $19,81 \%$ & Very good \\
\hline 4 & 140 & $46,76 \%$ & Well \\
\hline 3 & 68 & $22,52 \%$ & Pretty good \\
\hline 2 & 33 & $10,90 \%$ & Not good \\
\hline 1 & 0 & $0,00 \%$ & Poor \\
\hline Amount & 300 & $100 \%$ & - \\
\hline
\end{tabular}

While in diagram form can be seen in Figure 7. below:

\section{PRODUCTCOMPONENTS}

While in the form of bar charts can be seen in Figure 6 below:

\section{PROCESS COMPO NENTS}

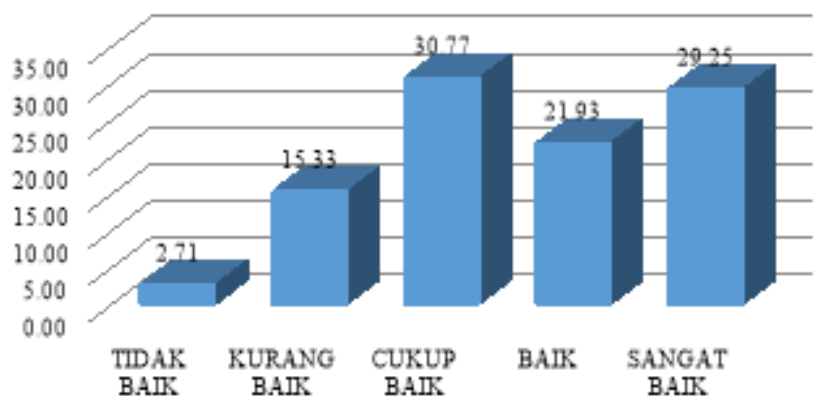

Fig. 6. Evaluation Results of Sub-Process Programs

Based on Table 4.12 and Figure 4.3 bar diagram above about the results of research data sub-focus of the evaluation process includes four things, namely: 1) competition rules 2) implementation, 3 ) the level of community participation and

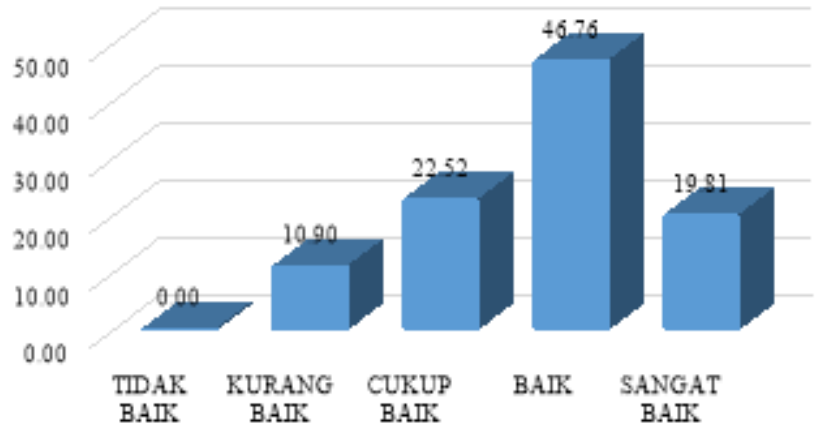

Fig. 7. Bar Diagram of Sub Product Evaluation Program Results

Based on Table 4. and Figure 7 pie diagram above about the results of research data sub-focus of product evaluation includes three things, namely: 1) clarity about the level of participation and public interest, 2) the role of the media in the publication and promotion of sports to the community, and 3 ) the emergence potential sportsman seeds from the community. Product evaluation results of 300 respondents stated 59 respondents $(19.81 \%)$ stated very good, 140 
system that boils down to maximum achievement. From the

respondents $(46.76 \%)$ stated good, 68 respondents $(22.52 \%)$ stated that it was quite good, 33 respondents $(10.90 \%)$ stated less well, and not respondents who stated not good. Thus the results of research on sub-focus data from product evaluation include three things, namely: 1) clarity about the level of participation and public interest, 2) the role of the media in the publication and promotion of sports to the community, and 3) the emergence of potential sportsman seeds from the community is well categorized.

\section{CONCLUSION}

Based on the discussion about the 2017 U-12 Menpora Cup Student League program it can be concluded, namely: (1) The process of selecting the participants of the 2017 Menpora Cup U-12 Student League refers to the achievements obtained by athletes both at the regional and national levels, from the results of the U-12 Student League Competition for the 2016 Menpora Cup regarding expectations of the efforts of fostering young soccer athletes the achievement has been good namely through professional selection (there are conditions); (2) The implementation of the 2017 Menpora Cup U-12 Student League program runs regularly and continuously, from the results of the evaluation of the U-12 Student League Cup the 2017 Menpora Cup regarding aspects of the implementation of its achievement program is already good namely the existence of ongoing competition; (3) Facilities and supporting infrastructure as a whole are in a good level and appropriate for use. From the results of the evaluation of the 2017 U-12 Menpora Cup Student League coaching program regarding the aspects of facilities and infrastructure, the achievement has been good, namely the completeness and feasibility of facilities and infrastructure; (4) The 2017 U-12 Menpora Cup Student League applies a positive and competitive results of evaluating the football coaching program through the U-12 Student League Cup Menpora Year 2017 regarding aspects of competition rules, the achievement is good, namely the application of a good and accountable competition system.

\section{ACKNOWLEDGMENT}

We want to thank the Ministry of Youth and Sports of the Republic of Indonesia, who has supported us in the form of funding. Therefore we can take part in this international seminar.

\section{REFERENCES}

[1] A. Palmizal, "The Evaluation of Provincial Sport Training Center (Pelatda) Towards National Sport Competion (PON) XIX/2016 West Java," JIPES - Journal of Indonesian Physical Education and Sport, vol. 3, pp. 48 - 58, https://doi.org/10.21009/jipes.031.07, 2017.

[2] Austrian Development Agency, "Guidelines for Project and Programme Evaluations," Austrian Development Cooperation, 1(July), 48. Retrieved from http://www.entwicklung.at/uploads/media/ Guidelines_for_Project_and_Progamme_Evaluations_FINAL_DRAFT Juli_2009.PDF, 2009.

[3] J. Galvin, "Program Evaluation Methods," PUB TYPE Collected Works-General (020)-_Guides__ .... Retrieved from http://scholar. google.com/scholar?hl=en\&btnG=Search\&q=intitle:PROGRAM+EV ALUATION+METHODS+:\#2, 1992.

[4] A. Paranoan and A. P. Nur, "Pengembangan Model Latihan Build Up Menyerang Pada Permainan Futsal," Jurnal Ilmiah Sport Coaching And Education, Vol. 1, pp. 79 - 92, Januari 2019.

[5] V. C. X. Wang, Evaluations Models for Evaluation (X. Wu, Ed.), China: Zhejiang University Press, Hangzhou and IGI Global, Hershey., 2009. 